\title{
Teologi Biblika Kontekstual di Seputar Persoalan Perempuan, Keturunan, dan Kemandulan
}

\author{
Yohanes Krismantyo Susanta* \\ Institut Agama Kristen Negeri Toraja, Indonesia; yohanessusanta@gmail.com \\ * Correspondence
}

Received: 2020-03-29; Accepted: 2020-08-02; Published: 2020-08-29

\begin{abstract}
The issues raised in this article are women and infertility in the context of Christian theology. Interpretation of biblical texts and Christian traditions has led to injustice and discrimination, especially for women. Therefore, constructive and contextual theology is needed to realize the liberation from theological understandings for women and men. The goal of this study is to offer contextual biblical theology so that the meeting between culture and biblical texts produces a spirit of equality, a spirit that liberates and upholds human values. This study employs a qualitative method of library research analysing the bible and books related to the topic. Using the synthesis model, this article shows that a reinterpretation of the texts of the Scriptures is necessary. Reinterpretation includes the nature and purpose of marriage, the role and position of women, and the theological meaning behind the story of infertility in the Scriptures. The purpose of marriage must be understood in the maturity of faith that each husband and wife are called to enjoy exclusive togetherness in the context of a covenant with God as the initiator. The Bible shows that from the very beginning, God created humans, men, and women in His image. This indicates that men and women have an equal position even though they have differences. Meanwhile, barrenness becomes rhetoric that lifts stories from women in ancient times to emphasize that God is the owner of the womb, and He has the power to control whom, when, and how pregnancy occurs.
\end{abstract}

Keywords: contextual biblical theology; heredity; infertility; women.

Abstrak: Masalah yang diangkat dalam artikel ini adalah perempuan dan kemandulan dalam konteks teologi Kristen. Penafsiran teks-teks Alkitab dan tradisi Kristen telah menyebabkan ketidakadilan dan diskriminasi, terutama bagi perempuan. Oleh karena itu, sebuah teologi konstruktif dan kontekstual diperlukan untuk mewujudkan pemahaman yang membebaskan bagi perempuan dan laki-laki. Penelitian ini menggunakan metode kualitatif dengan kajian pustaka atas Kitab Injil dan buku-bulu terkait. Tujuan yang ingin dicapai adalah menawarkan teologi biblika kontekstual sehingga pertemuan antara budaya dan teks Alkitab menghasilkan semangat kesetaraan, semangat yang membebaskan dan menjunjung tinggi nilai-nilai kemanusiaan. Dengan menggunakan pendekatan model sintesis, artikel ini menunjukkan bahwa penafsiran kembali terhadap teks-teks Kitab Suci, sangat diperlukan. Penafsiran ulang mencakup hakikat dan tujuan pernikahan, peran dan posisi perempuan, serta makna teologis di balik kisah kemandulan dalam Kitab Suci. Tujuan pernikahan harus dipahami dalam kedewasan iman bahwa setiap suami istri dipanggil untuk menikmati kebersamaan secara eksklusif dalam rangka perjanjian dengan Allah sebagai inisiatornya. Alkitab menunjukkan bahwa sejak semula, Allah menciptakan manusia, lakilaki dan perempuan menurut gambar-Nya. Hal ini menunjukkan bahwa laki-laki dan perempuan mempunyai kedudukan yang setara meskipun memiliki perbedaan. Sementara itu, kemandulan menjadi sebuah retorika yang mengangkat cerita-cerita dari perempuan di zaman kuno untuk menekankan bahwa Tuhan adalah pemilik rahim dan Ia sendiri yang berkuasa mengatur siapa, kapan, dan bagaimana kehamilan terjadi.

Kata Kunci: kemandulan; keturunan; perempuan; teologi biblika kontekstual. 


\section{Pendahuluan}

Kehadiran keturunan dalam sebuah keluarga dianggap sebagai pelengkap kebahagiaan suami istri, tak terkecuali bagi keluarga Kristen. Hal yang kontras dengan itu, kemandulan, menjadi salah satu sumber penderitaan dan kesedihan yang mendalam bagi sebuah keluarga. Berbagai usaha dilakukan oleh pasangan suami istri untuk dapat keluar dari situasi yang mungkin tidak pernah mereka pikirkan sebelumnya. Kegagalan memiliki keturunan kerapkali dipandang sebagai kesalahan pihak perempuan. Praktik budaya yang dikenal sebagai budaya patriarki yang menindas perempuan tersebut justru dan seolah mendapatkan legitimasi dan dukungan dari penafsiran atas teks-teks Alkitab dan tradisi Kristen mengenai perempuan yang selama ini dipelihara. Beberapa contoh penafsiran dan tradisi Kristen yang menindas kaum perempuan tersebut akan dijelaskan secara gamblang dalam artikel ini.

Persoalan keturunan berpotensi untuk memunculkan diskriminasi dan ketidakadilan, dalam hal ini yang seringkali menjadi korban adalah perempuan. Beberapa hasil penelitian mengungkap fakta tersebut. Penelitian yang dilakukan oleh Naimah pada tahun 2015 menunjukkan bahwa bias gender masih dengan mudah dijumpai di Indonesia yaitu pemahaman bahwa ketidakmampuan mempunyai anak disebabkan oleh kemandulan pihak istri atau perempuan (Naimah, 2015). Hal tersebut dipertegas oleh penelitian Panigoro pada tahun 2020 menunjukkan bahwa umumnya masyarakat masih menganggap bahwa kemandulan hanya dialami oleh perempuan, padahal laki-laki memiliki potensi yang sama besar (Panigoro, 2020). Penelitian Susanti dan Nurchayati di tahun 2019 menunjukkan bahwa masalah dan tekanan psikologis banyak dialami oleh perempuan yang menikah tanpa keturunan (Susanti \& Nurchayati, 2019). Tekanan sosial yang mengerikan memang dialami oleh para perempuan di tengah budaya yang menekankan dominasi laki-laki (Susanta, 2019).

Sementara itu, penelitian teologis tentang persoalan perempuan yang tidak mempunyai anak pernah penulis bahas sebelumnya dalam artikel berjudul "Makna Teologis Keturunan Sebagai Pemberian Allah Bagi Keluarga Dalam Perjanjian Lama"(Susanta, 2017). Artikel tersebut lebih menekankan pada arti penting keturunan bagi kehidupan keluarga Israel dan tidak banyak mengulas persoalan yang dihadapi oleh perempuan terkait kemandulan yang dialaminya. Secara khusus, dalam bidang teologi, sejauh penelitian penulis, belum ada buku yang secara khusus membahas persoalan keturunan dan kemandulan dari perspektif Perjanjian Lama (PL). Satu-satunya karya tulis yang membahas masalah keturunan dan kemandulan dalam bidang PL adalah tesis yang ditulis oleh Sarah Derck. Dalam tesisnya, Derck melakukan survei terhadap perempuan-perempuan mandul yang muncul di dalam Alkitab. Derck menyimpulkan bahwa kisah-kisah tersebut merupakan sebuah metafora teologis yang memperlihatkan bahwa perempuan mandul memegang peran penting dalam sejarah keselamatan, dahulu dan sekarang (Derck, 2002).

Dalam sejumlah jurnal, persoalan kemandulan dapat dijumpai dalam tulisan-tulisan Indra Sanjaya, John Byron, dan Scott Ashmon and Robert W. Weise. Sanjaya memperlihatkan bahwa dalam keluarga Israel kuno, kehadiran seorang anak sangat penting terutama untuk alasan ekonomis, keamanan, dan penghormatan leluhur. Oleh karena itu, seorang perempuan Israel memiliki peran penting dalam melahirkan anak-anak dan dalam hal ini, kemandulan menjadi sebuah persoalan serius bagi mereka (Sanjaya, 2014). Byron menyorot nasib istri yang mandul dalam keluarga Israel, yang menghadapi ancaman perceraian dan ancaman akan masa depannya jika sang suami berpoligami atau mengambil budak perempuan (Byron, 2010). Sementara itu, Ashmon dan Weise lebih banyak memusatkan perhatian pada kisah pergumulan Sarah, Rahel, dan Ribka dalam mengharapkan kehadiran seorang anak dari suami mereka (Ashmon \& Weise, 1988). Masing-masing tulisan yang dihasilkan dari beberapa jurnal tersebut memiliki fokus yang berbeda. Sanjaya menekankan alasan di balik pentingnya keturunan bagi Israel dan nasib perempuan-perempuan mandul dalam Alkitab. Byron memusatkan perhatian pada persoalan hidup rumah tangga yang dialami oleh istri dari keluarga Israel kuno yang mandul. Sementara Ashmon dan Weise memusatkan perhatian pada narasi pergumulan para ibu leluhur (matriarch) Israel. Oleh karena itu, meskipun tetap akan memanfaatkan penelitian yang sudah dilakukan, artikel ini tidak akan mengkaji sesuatu yang persis sama dengan tulisan yang sudah dihasilkan sebelumnya. 
Tulisan ini akan mengurai persoalan persoalan perempuan dan kemandulan dalam tradisi Kitab Suci Perjanjian Lama dan menghubungkannya dengan konteks masa kini guna membangun pemahaman teologi kontekstual untuk kehidupan umat. Pernyataan tesis dari artikel ini ialah budaya dan penafsiran atas teks Alkitab serta tradisi Kristen telah menimbulkan ketidakadilan dan diskriminasi khususnya kepada kaum perempuan sehingga diperlukan sebuah dialog yang konstruktif dan kontekstual di antara keduanya untuk memunculkan pemahaman yang membebaskan, baik bagi perempuan maupun laki-laki (kesetaraan). Tujuan yang hendak dicapai melalui artikel ini adalah menawarkan sebuah teologi yang bersifat kontekstual dan konstruktif sehingga perjumpaan antara budaya dan teks Alkitab (Kekristenan) diharapkan akan menghasilkan semangat yang baru, semangat yang berbeda, yang membebaskan sekaligus menjunjung tinggi nilainilai kemanusiaan.

Terkait sumber data, tulisan ini menggunakan metode kualitatif yaitu model studi pustaka. Penelitian kepustakaan dilakukan melalui buku-buku, Alkitab (baik dalam bahasa asli maupun sejumlah terjemahan), leksikon, ensiklopedi, jurnal, tafsiran, kamus teologi, dan literatur lain yang terkait dengan topik artikel ini. Stephen Bevans dalam buku berjudul "Models of Contextual Theology" menguraikan enam model pendekatan yang biasa dipakai dalam teologi kontekstual. Keenam model tersebut adalah model translasi, model antropologi, model praksis, model sintesis, model transendental, dan model counterculture. Model atau metode yang dipakai dalam tulisan ini adalah model sintesis. Model teologi sintesis adalah model yang menunjuk pada pengertian bahwa model teologi ini menjangkau konteks yang lain. Dengan kata lain teologi dibangun di atas dasar sudut pandang budaya seseorang dan budaya orang lain. Pada satu sisi, model ini berusaha menekankan integritas pesan tradisional (Alkitab dan warisan teologis), di sisi lain, model ini juga mengakui peran penting dari konteks masa kini. Hal ini berarti terdapat sebuah dialog kritis timbal balik antara konteks masa lalu dengan konteks masa kini (Bevans, 1992). Model ini bekerja dengan cara memberikan ruang bagi kedua konteks (Kekristenan dan budaya) untuk berdialog secara terbuka. Model sintesis merupakan model jalan tengah, yang melihat bahwa identitas Kristen (Injil) itu penting, tetapi tidak membuang atau mengesampingkan kultur (kebudayaan). Jadi, menurut model ini, Injil dan kultur sama- sama penting, sehingga Injil dan kultur kemudian didialogkan untuk berteologi (Bevans, 1992).

Persoalan tentang perempuan dan kemandulan tentu saja tak dapat dilepaskan dari beberapa konsep yang menyertainya yaitu terkait dengan nilai anak serta pemahaman akan hakikat dan tujuan perkawinan serta pemahaman keagamaan atau tafsir atas teks Kitab Suci. Oleh karena itu, bagian selanjutnya dari artikel ini akan membahas persoalan tersebut dari perspektif Kristen, secara khusus dari sudut pandang Teologi Perjanjian Lama untuk membangun pemahaman teologis yang kontekstual.

\section{Nilai Anak dalam Kitab Perjanjian Lama}

Pada kitab pertama dalam Alkitab terdapat perintah Allah kepada manusia agar mereka bertambah banyak jumlahnya dengan jalan bereproduksi (Kej. 1:28). Demikian pula ketika Rut hendak menikah dengan Boas, harapan atau ungkapan yang senada juga dapat ditemukan yaitu agar Rut melahirkan banyak keturunan bagi Boas dan kaum keluarganya (Rut 4:11-12). Hal ini memberikan indikasi yang kuat bahwa keturunan (dalam jumlah banyak) merupakan sesuatu yang sangat diharapkan oleh setiap keluarga di zaman Perjanjian Lama. Tujuan dari sebuah perkawinan dalam keluarga adalah untuk memperoleh keturunan. Menurut Roland deVaux, bagi orang-orang di era Perjanjian Lama, memiliki banyak anak merupakan sebuah kehormatan (De Vaux, 1997). Hal senada disampaikan oleh Leo Perdue bahwa memiliki banyak anak, khususnya anak laki-laki memiliki nilai yang sangat tinggi (Kej. 30:1; 1Sam 2:5: Mzm. 127: 3-5: 128: 3-4), dan mereka menyediakan bagi keluarga, baik jaminan ekonomi maupun status sosial (Kej. 16:5; 30: 1) (Perdue, 1997). Hal tersebut dipertegas oleh Yonky Karman yang mengatakan, "banyak anak adalah ideal keluarga di zaman kuno (mahkota orang-orang tua adalah anak cucu, Ams. 17:6)" (Karman, 2004). Keluarga di zaman Perjanjian Lama memusatkan perhatian kepada anak bukan hanya sebagai 
penyokong ekonomi keluarga di masa depan melainkan juga sebagai penerus dan penyambung garis keturunan nenek moyang keluarga. Bahkan mereka juga akan menjadi tempat menggantungkan hidup pada masa tua. Faktor tersebut -menurut Perdue- kemungkinan dapat menjelaskan mengapa tidak ada referensi di dalam Kitab Suci yang menunjuk kepada aborsi atau pembunuhan bayi (Perdue, 1997).

Sementara itu, seorang anak perempuan sangat bermanfaat bagi keluarga dan turut andil dalam melaksanakan pekerjaan keluarga ketika muda. Ketika anak perempuan tersebut menikah dan meninggalkan keluarganya, ayah dan keluarganya akan menerima kompensasi dari kehilangan tersebut dalam bentuk mohar (mas kawin) (Perdue, 1997). Anak perempuan akan menerima warisan ayahnya jika ia (ayah) tidak memiliki anak laki-laki atau jika ia (perempuan) menikah dengan orang dari pihak keluarga sang ayah (Bil. 27:1-11; 36: 1-12) (Perdue, 1997).

Jelaslah bahwa kehadiran seorang anak sangat penting artinya. Menurut Perdue, "berita kehamilan adalah kabar sukacita dan hari kelahiran merupakan sebuah perayaan yang penting bagi anggota keluarga" (Perdue, 1997). Hal tersebut memperlihatkan bahwa sejak zaman kuno, kehamilan dan kelahiran adalah dua peristiwa penting yang sangat dinantikan. Bahkan, menurut Albertz, kehamilan dipandang sebagai sebuah proses supernatural yang melaluinya Allah menciptakan individu baru di dalam rahim seorang ibu (Yer 1:5; Mzm. 139:13; Ayb. 10:8-11; 31:15; Yes. 49:1, 5). Penciptaan manusia pertama dan masa kehamilan serta kelahiran memiliki kaitan yang erat (Ayb. 10:8-11) (Albertz \& Schmitt, 2012). Anak yang lahir akan berada di bawah pengasuhan dan perlindungan keluarga, khususnya sang ibu. Hal tersebut tidak mengherankan sebab salah satu kenyataan pahit yang dihadapi oleh keluarga adalah tingginya angka kematian bayi yang biasanya disebabkan oleh berbagai macam wabah penyakit (Perdue, 1997). Dari hal tersebut, tampak bahwa tujuan sebuah perkawinan adalah untuk memperoleh keturunan. Keturunan yang dimaksud adalah anak dengan jenis kelamin laki-laki untuk meneruskan garis keturunan keluarga dan pada akhirnya menekankan dominasi laki-laki (patriarki).

\section{Perempuan dalam Keluarga di Era Perjanjian Lama}

Pada zaman Perjanjian Lama, peran perempuan atau istri yang paling penting adalah melahirkan banyak anak untuk menambah jumlah anggota keluarga besar (Kej. 24:60). Hal ini sekaligus menunjukkan bahwa kelangsungan hidup komunitas bergantung pada kesuburan seorang perempuan. Oleh karena itu tidak mengherankan jika Carol Meyers mengatakan bahwa reproduksi dalam konteks zaman kuno bukan sekadar proses biologis semata (perempuan melahirkan) melainkan merupakan bagian yang integral dengan isu kelangsungan hidup keluarga (family survival) (Meyers, 1997). Orang-orang pada zaman Alkitab adalah bagian dari masyarakat ekonomi agraris yang bergantung kepada keluarga besar (membutuhkan banyak keturunan untuk menambah jumlah anggota keluarga, membantu pekerjaan, dan mempertahankan diri), tetapi penyakit endemik dan epidemik telah membuat tingginya angka kematian bayi dan anak-anak (Meyers, 1997). Para ahli memperkirakan bahwa satu sampai tiga dari semua bayi meninggal selama bulan-bulan pertama setelah kelahiran, dan hal tersebut berarti setengah dari jumlah anak-anak tidak mampu bertahan hidup sampai dewasa (Albertz \& Schmitt, 2012). Dalam situasi demikian, bisa dibayangkan kesulitan yang dihadapi oleh seorang perempuan (baca: istri). Di satu sisi, ia harus mampu memberikan banyak keturunan. Akan tetapi di sisi lain, kondisi kesehatan yang buruk akibat kelaparan ataupun wabah penyakit menjadi ancaman baik bagi perempuan maupun bagi kelangsungan hidup anakanak yang akan dilahirkannya.

Di dalam masyarakat zaman itu, seorang istri tanpa anak-anak seringkali mendapat tekanan sosial yang mengerikan. Di Mesopotamia, perkawinan tanpa kehadiran seorang anak sering dianggap sebagai penolakan para dewa karena dosa yang telah dilakukan. Sebuah doa kepada dewi bulan (moon-god) Mesopotamia dinaikkan sebagai permintaan untuk pendamaian dari dosa dan diberikan keturunan/ anak-anak. Doa yang sama juga ditujukan kepada dewi Ishtar oleh istri atau pasangan suami istri yang berisi janji kepada para dewa dengan harapan mereka akan segera memperoleh keturunan (Marsman, 2003). Van der Toorn mengatakan bahwa "seorang perempuan 
yang kesulitan memiliki anak tidak hanya berjuang melawan penghinaan, cela dan pengabaian dari suami. Secara hukum, ia juga menghadapi kecurigaan masyarakat akan dosa atau kesalahan yang ia lakukan" (Van der Toorn, 1994). Bahkan, meskipun seorang istri mengandung namun mengalami kesulitan pada masa kehamilan atau pada saat melahirkan atau anak yang dilahirkan tidak sehat, hal tersebut juga ditafsirkan sebagai akibat dari dosa yang dilakukan (Byron, 2010). Dengan demikian, di dunia Timur Dekat kuno dan sekitarnya, fokus terhadap persoalan kemandulan umumnya ditujukan kepada kaum perempuan atau istri.

Menurut Indra Sanjaya, hal ini sekaligus berarti bahwa perempuan dipandang pertama-tama dalam fungsinya sebagai pemberi keturunan dan hal ini berarti bahwa perempuan praktis tidak mempunyai kontrol atas seksualitasnya sendiri (Sanjaya, 2014). Mengandung dan melahirkan anak mengandung risiko tersendiri bagi seorang perempuan. Menurut Meyers, angka kematian perempuan yang melahirkan sangat tinggi. Jika harapan hidup laki-laki sekitar 40 tahun, maka perempuan lebih rendah yaitu 30 tahun. Meyers menunjuk kepada Rahel sebagai representatif dari perempuan yang meninggal setelah melahirkan anak keduanya (Kej. 35:16-18) (Meyers, 1988). Berhadapan dengan kenyataan tersebut, seorang perempuan bisa saja memilih untuk tidak memiliki keturunan mengingat kesulitan dan risiko yang ditanggung oleh seorang perempuan hamil dan calon anak yang akan dilahirkannya. Akan tetapi, tampaknya di tengah situasi kehidupan yang serba sulit itu, seorang perempuan harus meletakkan kepentingannya di bawah kepentingan kolektif yaitu keluarga besarnya.

\section{Diskriminasi terhadap Perempuan: Pengaruh Budaya, Tafsir, dan Tradisi Kristen}

Jika sebuah keluarga tidak kunjung memiliki anak, pihak perempuan akan dipersalahkan dan dalam beberapa kasus bisa diceraikan. Sayangnya, hal tersebut justru diperparah dengan penafsiran klasik atas teks Alkitab yang sarat dengan muatan negatif terhadap peran dan posisi perempuan tak terkecuali terkait dengan soal melahirkan anak. Pola pikir yang beranggapan bahwa melahirkan adalah kewajiban perempuan berasal dari penafsiran atas Kejadian 3:16-18 yang mengatakan bahwa perempuan akan mengalami sakit bersalin sementara laki-laki harus bekerja keras membanting tulang sebagai konsekuensi dari pelanggaran yang mereka lakukan. Hal tersebut seolah dipertegas dalam tulisan rasul Paulus: "Tetapi perempuan akan diselamatkan karena melahirkan anak, asal ia bertekun dalam iman dan kasih dan pengudusan dengan segala kesederhanaan" (1Tim. 2:15). Penafsiran klasik atas teks tersebut dan beberapa teks lain dalam Alkitab justru makin mempertegas dominasi (penindasan) laki-laki kepada perempuan. Penafsiran atas teks tersebut mengukuhkan pandangan bahwa melahirkan merupakan kodrat sekaligus kewajiban seorang perempuan yang harus dipenuhi dalam kehidupan sebuah perkawinan.

Hal senada juga diungkapkan Phyllis Trible terkait dengan kekuatan oppressive dari penafsiran yang menyudutkan perempuan. Menurut Trible, jejak diskriminasi dan kekerasan terhadap perempuan yang terjadi di masyarakat dapat ditelusuri dari tradisi dan ajaran teologis yang bersumber dari penafsiran klasik yang memberi kesan negatif dan menyudutkan perempuan. Teks yang seringkali dijadikan acuan adalah Kejadian 2 dan 3 yang seolah mengindikasikan bahwa lakilaki lebih superior daripada perempuan dan kaum perempuan harus tunduk di bawah kuasa lakilaki (Kej. 2:7, 21-23; 3:6, dan 3:16) (Trible, 1983).

Penafsiran yang semena-mena atas beberapa bagian teks Alkitab justru memunculkan bias gender yang akhirnya berkembang menjadi sikap diskriminasi khususnya terhadap perempuan, tidak hanya dalam urusan rumah tangga melainkan juga dalam berbagai aspek kehidupan lainnya. Celakanya, pandangan yang menyudutkan dan meminggirkan perempuan juga mewarnai tradisi dan sejarah Kekristenan yang turut dipengaruhi oleh pemikiran bapak-bapak gereja misalnya Tertulianus dalam risalatnya yang berjudul "On the Apparel of women," mengatakan:

You [women] are the devil's gateway; you are the unsealer of that (forbidden) tree; you are the first deserter of the divine law; you are she who persuaded him whom the devil was not valiant enough to attack. You destroyed so easily God's image, man. On account of your desert-that is, death-even the Son of God had to die... (Kvam, Schearing, \& Ziegler, 1999) 
Hal tersebut juga diikuti oleh John Chrysostom, seorang bapa gereja sekaligus uskup Agung Konstantinopel (347-407 M), yang memandang perempuan sebagai pihak yang lemah: "Then why is the 'man' said to be in the 'image of God' and woman not? ...'image' has rather to do with authority, and this only the man has; woman has it no longer" (Soskice, 1992). Hal ini jelas memperlihatkan bahwa tafsiran Chrysostom bersifat misogini karena memandang perempuan tak memiliki citra Allah dalam dirinya, tak seperti halnya kaum laki-laki.

Dari beberapa hal di atas tampak jelas bahwa perempuan dipandang sebagai pribadi yang lemah dan inferior dibandingkan laki-laki. Pemahaman yang merendahkan perempuan tidak hanya terjadi pada keluarga di zaman Alkitab melainkan juga pada masyarakat Yahudi masa kini. Bahkan, Rabbi Judah ben Elai mengatakan bahwa seorang laki-laki Yahudi setiap pagi senantiasa memanjatkan doa syukur yang berisi tiga hal: "[blessed art thou...] who hast not made me a heathen, ... who hast not made me a woman, ... and who hast not made me a brutish man"(Hurley, 1981). Hal ini sekali lagi menegaskan bahwa dalam pemahaman klasik terhadap Kitab Suci, terdapat kecenderungan merendahkan posisi perempuan.

\section{Berbagai Pilihan Pasangan yang Tidak Memiliki Anak di Zaman Kuno}

Kemandulan menjadi momok yang menakutkan yang dirasakan oleh keluarga yang hidup pada masa lampau. Berbagai usaha dilakukan oleh pasangan suami istri untuk keluar dari masalah kemandulan tersebut. Beberapa pilihan yang tersedia memungkinkan mereka keluar dari situasi yang tidak mengenakkan tersebut.

\section{Doa Memohon Keturunan}

Doa merupakan sarana untuk memohon kepada Tuhan termasuk untuk memohon keturunan. Doa yang paling banyak disampaikan pasangan suami istri kepada Allah mungkin adalah doa mohon keturunan (Sanjaya, 2014). Hal itu tidak mengherankan sebab sudah dipraktikkan oleh masyarakat kuno dan sekitarnya yang mengenal doa atau permohonan kepada Allah serta para dewa. Dalam doanya kepada dewi Ishtar, seorang perempuan berkata: "Grant me a name and descendants, let my womb be productive" (Van der Toorn, 1994). Hal ini dilakukan sebab Dewi Ishtar diyakini sebagai dewi kesuburan yang dapat mengabulkan permohonan para perempuan untuk mempunyai anak. Di dalam Alkitab juga dijumpai permohonan kepada Allah untuk mendapatkan keturunan. Di dalam Alkitab, sedikitnya dua kali hal tersebut dicatat yaitu ketika Ishak meminta Tuhan membuka rahim istrinya yang mandul (Kej. 25:21) dan ketika Hana berdoa memohon keturunan dan Tuhan mengabulkannya dengan memberikannya anak, Samuel (1Sam. 1:10-20).

\section{Pengobatan Alternatif}

Jika doa tidak berhasil, maka pengobatan atau cara alternatif ditempuh oleh keluarga. Hal yang senada juga dilakukan oleh masyarakat Babilonia. Sebuah teks kuno dari Babilonia menyebutkan: "Silver, gold, iron, copper, in total twenty one stones, in order that a woman who is not pregnant becomes pregnant; you string it on a linen yam and you put it on her neck" (Byron, 2010). Resep kuno masyarakat Mesir yang ditemukan lewat penelitian arkeologi juga menyebutkan: "You flay an edible mouse, open it up, and fill it with myrrh; you dry it in the shade, crush and grind it up, and mix it with fat; you place it in her vagina, and she will become pregnant" (Byron, 2010). Hasil penelitian arkeologi tersebut menunjukkan bahwa berbagai usaha termasuk kegiatan di luar nalar akan diupayakan karena diyakini akan menolong pasangan khususnya perempuan mandul untuk dapat mempunyai anak.

Sementara itu, di dalam Alkitab tidak dijumpai secara ekplisit praktik tersebut. Akan tetapi beberapa ahli meyakini bahwa hal itu dapat ditemukan dalam kisah Rahel yang meminta buah dudaim Ruben, anak sulung Lea. Buah dudaim diyakini sebagai buah yang dapat memancing hasrat seksual dan meningkatkan kesuburan perempuan. Selanjutnya, menurut Sanjaya, dalam upacara perkawinan di beberapa kelompok di Palestina modern, sebuah buah delima seringkali dibelah di ambang pintu rumah sang pengantin baru. Hal tersebut adalah tradisi dan harapan para sahabat 
yang hadir, semoga keturunan keluarga baru tersebut sebanyak biji delima yang berhamburan (Sanjaya, 2014).

\section{Mengangkat Anak (adopsi anak)}

Praktik pengangkatan anak karena kemandulan suami istri juga dijumpai dalam dunia kuno. Sejumlah kontrak adopsi dari Nippur mengungkapkan adanya praktik ini. Salah satu tablet yang rusak berbunyi: "[...] anak Inanna [...] telah diadopsi sebagai anaknya (atau telah diadopsi sebagai anak oleh) [...] anak laki-laki Siyatum dan telah menjadikannya ahli warisnya" (Byron, 2010). Praktik adopsi juga ditemukan di Mesir yang termuat dalam papirus yang mengisahkan cerita yang menarik mengenai adopsi yang dilakukan keluarga Mesir yang tidak mempunyai anak (Byron, 2010).

Meskipun praktik tersebut tampaknya berlaku secara umum di dunia kuno, hal yang menarik praktik tersebut tidak ditemukan secara jelas dalam Alkitab. Hanya ada dua kasus di mana relasi tersebut dijelaskan yaitu Keluaran 2:10, Musa diadopsi oleh putri Firaun, dan di Ester 2:7 kita membaca bahwa Mordekhai mengangkat keponakannya saat diasingkan di Persia. Hal tersebut memberikan indikasi bahwa praktik adopsi dapat ditemukan jejaknya dalam Alkitab tetapi tampaknya hal tersebut tidak dihadirkan sebagai salah satu alternatif bagi mereka yang tidak memiliki anak.

\section{Perceraian, Poligami, dan Ibu Pengganti}

Sementara itu, pilihan berupa praktik perkawinan yang tidak lazim bagi dunia modern dapat dijumpai dalam keluarga di zaman kuno. Keluarga yang tidak mempunyai anak berusaha untuk memperoleh anak sedikitnya dengan dua cara: mengambil istri lebih dari satu (poligami) atau menghampiri budak perempuan yang akan berperan sebagai ibu pengganti (surrogate mother) (Derck, 2002). Praktik poligami dengan alasan untuk memperoleh keturunan memang kurang jelas di Alkitab. Alkitab hanya menunjukkan bahwa praktik tersebut berlakutanpa menyebutkan secara pasti alasan atau hukum yang mengaturnya. Alkitab hanya menunjukkan bahwa praktik tersebut ada. Salah satu teks yang menunjukkan eksisitensi dari praktik tersebut adalah Ulangan 21:15-17.

Sebagian ahli berpendapat bahwa poligami adalah kebiasaan umum di zaman kuno (Gunkel, Wolff, Douglas) sedangkan yang lain berpendapat bahwa poligami hanya dipraktikkan di Israel dan Mesopotamia ketika istri pertama mandul. Narasi leluhur Israel memperlihatkan bahwa poligami merupakan praktik yang banyak terjadi (Albertz \& Schmitt, 2012). Meskipun praktik perkawinan poligami dapat ditemukan di masyarakat Israel dan Mesopotamia, hal yang menarik adalah dokumen kontrak perkawinan orang Yahudi di Elefantina, Mesir Selatan (600 SM) justru melarang seorang laki-laki menikahi istri kedua, kalau tidak ia akan menghadapi perceraian, kehilangan mas kawin, atau dikeluarkan dari ahli waris. Dengan demikian, tampaknya monogami merupakan bentuk perkawinan yang paling umum di dalam komunitas tertentu, dalam hal ini Elefantina. Sementara itu poligami merupakan kekecualian dan sering terjadi bila istri pertama mandul atau hanya melahirkan anak-anak perempuan (Albertz \& Schmitt, 2012). Hal tersebut menunjukkan bahwa seorang istri dituntut untuk mampu memberikan keturunan. Apabila hal tersebut tidak terpenuhi, maka seorang suami memiliki hak untuk mengambil istri lain dengan tujuan untuk dapat memperoleh keturunan.

Selanjutnya juga ditemukan praktik yang hampir mirip dengan poligami yaitu praktik ibu pengganti (surrogate mother). Praktik ibu pengganti terjadi apabila seorang suami dari istri yang mandul bersetubuh dengan budak istrinya (band. Kisah Abram dan Hagar). Budak perempuan tersebut adalah semacam "second-class wife" yang sangat berguna jika ia melahirkan anak laki-laki dan status anak yang dilahirkan adalah anak dari istri yang mandul (band. Kej. 35:25-26) (Perdue, 1997). Dengan kata lain, budak perempuan tersebut berperan sebagai seorang ibu pengganti bagi istri yang tidak mempunyai anak (Kej. 16 dan 21; 30:3; 9-13). Ibu pengganti merupakan tindakan yang diambil oleh beberapa perempuan di dalam Alkitab misalnya Sara, Rahel dan Lea dengan mengklaim tubuh perempuan lain sebagai perpanjangan (extension) dari diri mereka (Havrelock, 2008).

Dua praktik yang terjadi dalam perkawinan tersebut (poligami dan ibu pengganti) mengindikasikan bahwa di dalam keluarga di zaman kuno, fungsi seorang istri pertama-tama adalah 
untuk menghasilkan banyak keturunan. Jika demikian, dapat dibayangkan betapa menyedihkan dan malangnya seorang istri yang tidak memiliki anak. Suaminya dapat mengambil istri lagi, bahkan menceraikan istrinya karena dianggap tidak mampu memberikan keturunan. Di dalam perkembangannya, para rabbi Yahudi juga melegitimasi perceraian. Mazhab Hillel meyakini bahwa salah satu alasan suami menceraikan istri adalah karena tidak memiliki anak. Bahkan, Rabbi Hilel terkesan sangat membela kepentingan laki-laki, "a man might divorce his wife if she spoiled his food" (Hurley, 1981). Seorang laki-laki dengan mudah dapat menceraikan istrinya hanya karena masalah makanan.

Hal tersebut sekali lagi menunjukkan bahwa baik tradisi dan budaya kuno masih kurang ramah bagi perempuan serta tidak memperhatikan kepentingan dan hak mereka, bahkan cenderung menyuburkan tindak kekerasan dan diskriminasi kepada perempuan. Dapat diperkirakan salah satu akibat yang ditanggung oleh seorang istri yang diceraikan dalam kedua konteks tersebut: Siapa yang mau menikahi perempuan yang diceraikan dengan alasan karena tidak mampu memberikan keturunan dalam sebuah budaya yang sangat menekankan pentingnya keturunan?

\section{Memahami Ulang Hakikat dan Tujuan Pernikahan}

Keluarga-keluarga juga harus diberikan pemahaman yang tepat akan hakikat dan tujuan perkawinan yang Alkitabiah. Jika tujuan utama perkawinan adalah untuk memperoleh keturunan, maka tidak mengherankan jika berbagai usaha dilakukan termasuk menceraikan pasangan yang dianggap tidak mampu memberikan keturunan/mandul (dalam hal ini yang sering dipersalahkan adalah istri). Salah satu teks Alkitab yang selama ini dipahami sebagai tujuan dari sebuah perkawinan adalah Kejadian 1:28. Akibatnya, banyak pasangan yang kemungkinan merasakan tekanan dari perintah "beranak cuculah dan bertambah banyak" (Kej. 1:28). Terkait dengan hal tersebut, kemungkinan mereka (pasangan suami istri) tidak memahami bahwa konteks perintah tersebut diberikan kepada Adam dan Hawa (perwakilan dari semua umat manusia). Konsekuensinya, mereka kemungkinan tidak menyadari bahwa mungkin Allah membiarkan atau mengizinkan mereka tetap berada dalam situasi tersebut (tidak mempunyai anak) (Ashmon \& Weise, 1988). Dunia Timur Dekat Kuno dan sekitarnya tampaknya memang memberikan indikasi kuat bahwa tujuan utama dari sebuah perkawinan adalah untuk memperoleh keturunan, bahkan dalam jumlah yang besar. Akan tetapi perlu diingat konteks dan tuntutan zaman pada waktu itu yaitu untuk menyediakan tenaga kerja yang cukup dalam menunjang ekonomi keluarga sekaligus sebagai pertahanan dari serangan musuh/ perang. Hal tersebut tentu saja berbeda dengan konteks kehidupan keluarga pada masa kini.

Itu sebabnya perlu dilakukan reinterpretasi dan pemahaman ulang kepada jemaat Kristen atau pasangan suami istri terhadap bagian Alkitab atau kisah yang menunjukan bahwa tujuan pernikahan adalah untuk mendapatkan keturunan. Jika tidak, maka setiap pasangan yang menikah bisa saja berpikir bahwa tujuan pernikahan adalah untuk menggenapi rencana Tuhan, melahirkan keturunan sebagaimana yang tertuang dalam Kejadian 1:28 tersebut. Tujuan pernikahan Kristen harus dipahami dalam kedewasan iman bahwa setiap suami istri dipanggil untuk menikmati kebersamaan secara eksklusif dalam rangka perjanjian -dengan Allah sebagai inisiatornya- melalui cinta di antara pasangan suami istri tersebut (Purnomo, 2013). Suami istri hanya dapat berusaha tetapi mereka tidak dapat menentukan apalagi memaksakan untuk dapat memperoleh keturunan.

\section{Memahami Ulang Peran dan Kedudukan Perempuan}

Sejak semula berkembang pemahaman bahwa perempuan memiliki peran dan kedudukan yang lebih rendah daripada laki-laki. Konsep inilah yang perlu dikoreksi dan dikritisi. Untuk mengubah daya pikir masyarakat yang keliru memang tidak mudah dan diperlukan sebuah perjuangan yang panjang dan melelahkan. Tetapi bukan berarti orang Kristen, hanya dapat pasrah dalam menghadapi keadaan tersebut. Sebuah usaha harus dimulai dan dikerjakan. Sebuah reinterpretasi terhadap teks merupakan urgensi yang mutlak harus segera dilakukan dan dipraktikkan. 
Hal ini berarti diperlukan sebuah reinterpretasi atas teks-teks Alkitab yang selama ini ditafsirkan secara keliru dan membuat perempuan terpinggirkan. Padahal Alkitab sesungguhnya menunjukkan bahwa sejak semula, Allah menciptakan manusia, laki-laki dan perempuan menurut gambar-Nya. Dari situ saja sudah terlihat bahwa laki-laki dan perempuan mempunyai nilai dan kedudukan yang sama meskipun memiliki perbedaan. Berbeda namun setara. Pada akhirnya, karena kemandulan seringkali dianggap sebagai kesalahan pihak perempuan (karena perempuan yang melahirkan), maka selanjutnya perlu diberikan pemahaman yang tepat untuk mengoreksi hal tersebut. Hal ini pada akhirnya akan terkait erat dengan isu ketidakadilan gender. Anggapan bahwa ketidakmampuan keluarga memiliki anak adalah kesalahan dari pihak istri (baik di zaman kuno maupun yang terjadi sampai saat ini, meskipun kemajuan ilmu kesehatan menunjukkan bahwa tidak hanya perempuan saja yang mandul) sesungguhnya bermuara dari pemahaman yang keliru mengenai peran dan posisi perempuan.

Perempuan sebagai penolong tidak seharusnya diartikan sebagai asisten, pembantu, sebuah posisi yang lebih rendah dan memberi kesan martabat perempuan lebih rendah. Menurut Yonky Karman, tampaknya ada ketegangan antara kenyataan yang berlaku dan kesetaraan sebagai gambaran ideal yang dikehendaki Allah (Karman, 2004). Hal ini berarti bahwa sejak semula Allah menghendaki adanya kesetaraan: laki-laki dan perempuan sama-sama diciptakan menurut gambar Allah. Hal yang sama juga diungkapkan oleh Trible sebelumnya. Ia melakukan reinterpretasi terhadap teks kejadian 2 dan 3 yang seringkali menjadi legitimasi dominasi laki-laki atas perempuan. Tindakan Adam menamai istrinya tidak mengindikasikan bahwa pria lebih superior sebab nama yang diberikan (issa) bukanlah nama diri melainkan kata benda umum (Trible, 1983). Selain itu tidak dapat dibenarkan bahwa istri yang salah karena ia yang lebih dahulu melanggar perintah Allah. Hal yang harus diingat adalah perintah tersebut lebih dahulu diberikan kepada adam (suami) sehingga ia pun memikul tanggung jawab atas perintah tersebut.

Sementara itu, Kejadian 3:16 secara keseluruhan mengandung arti bahwa meskipun risiko dominasi suami dan sakit bersalin, keadaan tidak mengenakkan itu tidak menyurutkan niat perempuan untuk mengandung dan melahirkan (Trible, 1983). Sebagai tambahan, menurut Karman, "bagi perempuan, kutuk kejatuhan bukan terfokus pada gairah seksualnya. Keterarahan istri kepada suaminya adalah sesuatu yang wajar sama seperti suami terarah kepada istrinya" (Karman, 2004). Malahan, hal yang tak kalah menarik adalah istilah penolong yang disematkan pada diri perempuan mengandung makna yang berbeda dengan yang umumnya dipahami orang pada masa kini. Istilah tersebut sama sekali tidak berkonotasi sebagai subordinasi, atau pihak yang lebih inferior. Kata penolong (ezer) melukiskan kekuatan dan kata tersebut sering dipakai untuk mendeskripsikan Allah sebagai pihak yang superior, mencipta dan menyelamatkan (Trible, 1983). Hal lain yang perlu diingat bahwa setiap laki-laki membutuhkan perempuan. Kehamilan pun membutuhkan tubuh perempuan. Fakta tersebut seharusnya membuat laki-laki dapat menghargai dan menghormati perempuan serta mensyukuri kehadirannya sebagai anugerah Tuhan yang diberikan untuk menjadi teman, mitra, istri, dan penolong yang sepadan.

\section{Memahami Ulang Makna Teologis di Balik Kisah Kemandulan dalam Alkitab}

Menurut Walter Brueggemann, "kemandulan merupakan metafora untuk keputusasaan. Meskipun demikian, kemandulan juga merupakan arena dari karya hidup pemberian Allah (the arena of God's life-giving action)" (Brueggemann, 1982). Hal ini sesuai dengan beberapa kisah perempuan mandul (Sara, Ribka, Rahel, dan Hana) yang memperlihatkan bahwa keluarga-keluarga tersebut memulai kehidupan mereka di dalam sebuah situasi keputusasaan yang besar. Akan tetapi Tuhan memberikan jalan keluar dari situasi tersebut dengan memberikan anak kepada mereka. Kemandulan adalah sebuah konsep teologis yang penting di Perjanjian lama. Meskipun istilah untuk kemandulan tersebut (עָָָר) 'āqār hanya muncul 11 kali, tetapi istilah tersebut seringkali menunjuk kepada tujuan penebusan Allah yang terkait erat dengan perjanjian-Nya (covenant) (Brueggemann, 1982).

Ketika Tuhan memanggil Abram, Ia berjanji "Aku akan membuat engkau menjadi bangsa yang besar, dan memberkati engkau serta membuat namamu masyhur; dan engkau akan menjadi berkat... 
Aku akan memberikan negeri ini kepada keturunanmu" (Kej. 12:2,7). Ketika Allah mengadakan perjanjian dengannya, sebuah penegasan diberikan kepada Abram: "Coba lihat ke langit, hitunglah bintang-bintang, jika engkau dapat menghitungnya." Maka firman-Nya kepadanya: "Demikianlah banyaknya nanti keturunanmu" (Kej. 15:5). Janji tersebut diulangi kembali kepada Ishak (Kej. 26:3) dan Yakub (Kej. 28:13). Berhadapan dengan hal itu, kemandulan seolah menjadi penghalang dan tantangan bagi terwujudnya perjanjian tersebut. Menurut Rachel Havrelock, kemandulan memiliki dua dimensi. Kemandulan dapat dibaca sebagai krisis perjanjian (a crisis of covenant) dan ketiadaan relasi antara Allah dengan perempuan (the absence of relationship between woman and God) (Havrelock, 2008). Maka dapat dipahami bahwa tindakan Allah dalam memberikan anak kepada Sara, Ribka dan Rahel menunjukkan bahwa kuasa dan belas kasihan Allah mengatasi apa yang bagi manusia dianggap sebagai rintangan yang tak dapat diatasi (kemandulan) sekaligus memunculkan relasi antara Dia dengan perempuan (melalui konsepsi dan kelahiran). Dari rahim tersebut muncul figur penting bagi bangsa Israel yaitu Ishak, Yakub dan Yusuf. Kemunculan mereka menjadi tanda dan bukti atas janji dan pemeliharaan Tuhan atas hidup bangsa tersebut.

Sementara itu, pada bagian lain memang tampak bahwa kemandulan adalah hukuman Tuhan, misalnya Kejadian 20:17-18: "Lalu Abraham berdoa kepada Allah, dan Allah menyembuhkan Abimelekh dan isterinya dan budak-budaknya perempuan, sehingga mereka melahirkan anak.Sebab tadinya TUHAN telah menutup kandungan setiap perempuan di istana Abimelekh karena Sara, isteri Abraham itu." Akan tetapi hal tersebut tampaknya tidak bersifat universal. Kemandulan Sara, Ribka dan Rahel tidak dapat disimpulkan sebagai hukuman Tuhan atas dosa mereka. Penulis Kejadian secara sederhana hanya memperlihatkan kondisi mereka yang mandul tanpa penjelasan tentang penyebab dari kemandulan tersebut. Allah menjanjikan bahwa Sara akan melahirkan meskipun ia mandul. Ishak berdoa kepada Tuhan karena Ribka mandul dan Tuhan mengabulkan doanya. Sedangkan dalam kasus Rahel, penulis kejadian secara singkat mengatakan bahwa Rahel diingat oleh Tuhan sehingga ia mengandung dan melahirkan.

Tidak pernah ada penjelasan mengapa "Allah mengingat,"dan tidak juga dijelaskan mengapa ia (perempuan tersebut) dilupakan sebelumnya. Dari kasus-kasus tersebut tampak jelas bahwa tindakan Allah memberikan anak adalah untuk menghapus aib dan penderitaan ibu mereka. Sekali lagi, hal tersebut menjadi bukti dari kesetiaan Tuhan terhadap janji yang diikrarkan kepada nenek moyang mereka. Kemandulan menjadi sebuah retorika yang mengangkat cerita-cerita dari perempuan di zaman kuno untuk menekankan bahwa Tuhan adalah pemilik rahim perempuan dan Ia sendiri yang berkuasa untuk mengatur siapa, kapan, dan bagaimana kehamilan terjadi.

\section{Rahim Perempuan adalah Milik Allah}

Ketika Sara berada di istana Abimelekh, Tuhan menyelamatkannya dengan cara menutup rahim semua perempuan di istana tersebut yang membuat Abimelekh menyadari ada sesuatu yang salah yang telah ia lakukan. Akan tetapi setelah Abraham berdoa, maka para perempuan tersebut bisa mengandung. Kisah tersebut secara sederhana menunjukkan bahwa Allah menjadi pemilik rahim semua perempuan serta dapat menutup atau membuka rahim tersebut (Trible, 1983). Tindakan tersebut juga menjadi salah satu bukti intervensi Allah. Ia menutup rahim untuk melindungi rahim perempuan yang daripadanya anak yang dijanjikan Allah akan lahir (Ishak).

Allah bukan sekadar pemilik rahim tersebut tetapi narasi tentang perempuan-perempuan mandul dalam Alkitab juga menunjukkan bahwa kontrol atau kendali atas rahim perempuan bukanlah milik istri atau suami mereka, bukan pula milik janin itu sendiri, apalagi milik masyarakat (Trible, 1983). Perkataan Sara kepada Abram: "Engkau tahu, Tuhan tidak memberi aku melahirkan anak." (Kej. 16:2) dan jawaban Yakub kepada Rahel "Akukah pengganti Allah, yang telah menghalangi engkau mengandung?" (Kej. 30:2) mengindikasikan bahwa kontrol atasnya berada di tangan Allah sendiri. Rahim tersebut memang melindungi dan memelihara/ memberi makan individu yang ada di dalamnya. Tetapi kuasa atas rahim itu sendiri ada di tangan Allah. Ia yang menentukan apakah rahim itu akan dibuka (subur) atau dibiarkan tetap tetutup (mandul). 


\section{Allah Berkuasa Membentuk Individu dalam Rahim Perempuan}

Tidak hanya berkuasa mengontrol kesuburan perempuan dengan cara membuka atau menutup rahim, Allah juga bekerja pada organ tersebut untuk membentuk individu yang hidup. Hal yang sama juga dikemukakan oleh Albertz bahwa bagi orang di zaman kuno, selama fase kehamilan, Allah membentuk individu baru dalam rahim ibunya (Mzm. 13:13; Yer. 1:5; Ayb. 10:8-11) serta bertindak aktif sebagai bidan/ penjaga sang ibu dan anak. Masa kehamilan dan kelahiran anak dianggap sebagai lanjutan dari penciptaan manusia (bdk. Kej. 2:7; 4:1) (Albertz \& Schmitt, 2012). Allah tidak lagi menciptakan individu secara langsung melainkan melalui perantaraan rahim perempuan. Rahim perempuan tersebut sekaligus menjadi simbol kesetaraan, anak laki-laki dan perempuan keluar dari tempat yang sama: dari rahim seorang perempuan (Trible, 1983). Allah mengetahui waktu yang paling tepat untuk memberikan seorang anak sekaligus melenyapkan keputusasaan yang dirasakan oleh keluarga yang telah lama menantikan kehadiran keturunan. Tidak ada indikasi kuat bahwa kemandulan adalah hukuman Tuhan (kecuali kisah Sara di istana Abimelekh). Ketika Allah melenyapkan kemandulan para matriarkh, hal tersebut menunjukkan adanya intervensi Ilahi berupa berkat-Nya atas rahim perempuan sekaligus pemenuhan atas janji-Nya karena melalui para perempuan tersebut, lahir sosok penting dalam sejarah orang-orang di era Perjanjian Lama yaitu Ishak, Yakub, dan Yusuf. Bahkan, hal yang sama juga terjadi pada diri perempuan-perempuan mandul lainnya dalam Alkitab seperti Hana yang melahirkan Samuel atau istri Manoah yang melahirkan Simson.

\section{Kemandulan Sebagai Bagian dari Karya Allah yang Misterius}

Sebagaimana yang telah disinggung pada bagian sebelumnya, di Alkitab, kita menjumpai kisah keluarga-keluarga yang bergumul dengan masalah keturunan yang berakhir dengan sukacita. A happy ending. Lalu bagaimana dengan keluarga-keluarga masa kini yang bergumul dan berada pada situasi yang sama seperti keluarga-keluarga tersebut? Mereka pun mengharapkan kehadiran anak dalam perkawinan mereka. Maka tidak heran jika doa memohon keturunan menjadi salah satu doa yang seringkali kita dengar di gereja. Dalam situasi yang serba sulit tersebut, bisa saja mereka berpikir bahwa Allah tidak memperhatikan mereka meskipun mereka setia kepada-Nya. Apakah teks Alkitab yang terkesan memberi harapan bagi keluarga yang tidak memiliki keturunan hanyalah sebuah hiburan semu? Mengapa Allah pada satu sisi membebaskan penderitaan para matriakh tetapi di sisi lain membiarkan perempuan-perempuan pada masa kini tetap berada pada situasi malang tersebut? Bukankah Dia adalah Allah yang sama dan tidak berubah? Meskipun makna teologis di balik kisah perempuan mandul dalam Alkitab telah dijelaskan sebelumnya, akan tetapi persoalan kemandulan yang dihadapi dan digumuli oleh keluarga pada masa kini perlu mendapat perhatian dan penjelasan lebih lanjut.

Untuk menanggapi pertanyaan dan kegelisahan keluarga tersebut, pertama, harus diingat sebagaimana yang telah disebutkan sebelumnya,- bahwa kisah kemandulan yang dialami oleh leluhur orang Perjanjian Lama (para matriarkh) adalah sebuah metafora keputusasaan. Selain itu, kisah-kisah tersebut merupakan retorika yang memiliki tujuan teologis. Alkitab mencatat kisah perempuan mandul yang berakhir dengan kebahagiaan (akhirnya dapat mengandung dan melahirkan). Tindakan Allah melepaskan seseorang dari kemandulan menjadi sebuah retorika akan kuasa, kasih, dan kesetiaan Tuhan dalam menggenapi perjanjian dengan umat-Nya, meskipun Ia sebenarnya tidak berkewajiban untuk melakukannya. Kisah-kisah perempuan mandul di dalam Alkitab pertama-tama tidak dimaksudkan untuk mengajarkan bahwa setiap kasus kemandulan yang terjadi sampai saat ini pasti akan berakhir bahagia. Sebab, happy ending (akhir yang bahagia) bukanlah pesan dari cerita-cerita tersebut tetapi bagaimana intervensi Allah dalam kehidupan sebuah keluarga. Singkat kata, kisah-kisah tersebut diangkat dan diceritakan sebagai usaha untuk menggambarkan kasih setia dan belas kasihan Tuhan kepada umat-Nya dan tidak dapat dipandang sebagai sesuatu yang normatif atau menjadi tolok ukur bagi kasus-kasus serupa yang terjadi pada masa kini. 
Kedua, harus diingat bahwa kisah-kisah tersebut jangan dipandang sebagai pembenaran bahwa Allah pasti (baca: harus) menolong umat-Nya (termasuk untuk memperoleh keturunan). Allah mahakuasa tetapi Ia juga adalah Allah yang bebas. Tidak ada manusia yang dapat mengontrol atau mengendalikan kehendak-Nya. Manusia tidak bisa menuntut Dia dengan dalil bahwa Ia harus setia terhadap perjanjian karena justru manusialah yang acapkali tidak setia. Sejarah Perjanjian Lama sebagaimana yang tercatat di dalam dan sejarah umat manusia sepanjang zaman telah membuktikannya. Terkait dengan sifat Allah yang bebas ini, Agustinus Setiawidi juga mengatakan bahwa Allah bisa menghukum dan membalas, tetapi ia pun dapat tersentuh hatinya, terharu, dan kembali menyayangi (Setiawidi, 2014). Lebih lanjut, Setiawidi juga mengatakan bahwa kesalahan manusia adalah menganggap bahwa Allah di dalam Alkitab itu bisa "dijinakkan, dibungkus, dan dinikmati sesuai selera." Itu sebabnya jika manusia mengalami kesulitan dan penderitaan dalam hidupnya ia berpikir bahwa Allah akan menjadi penyedia solusi yang paling cepat dan tepat (Setiawidi, 2014). Bahaya dari pemahaman ini adalah bahwa kita menempatkan diri kita di tempat Allah. Manusia tidak menempatkan diri sebagai pelayan dan mitra Allah, justru sebaliknya, manusia menempatkan Allah sebagai pelayannya. Bahkan di dalam Kekristenan, orang Kristen seolah tidak memahami esensi dan makna dari Allah yang merendahkan diri (misalnya Filipi 2:1-11). Entah sadar atau tidak, hal tersebut justru dianggap sebagai hal yang wajar, bahkan menjadi kewajiban Allah!

Pemahaman bahwa Allah adalah mahakuasa, mahakasih, mahapengampun, dan lain sebagainya membuat manusia merasa nyaman dengan hidupnya karena merasa telah memiliki jaminan. Bahaya dari pemahaman ini adalah jika pengharapan yang dimiliki tidak sejalan dengan realita hidup yang dialami, maka manusia bisa jatuh ke dalam kekecewaan. Ketika penderitaan hadir, tantangan dan kesulitan tidak kunjung berhenti, doa dan keinginan tidak terwujud, manusia dengan mudah akan mencari solusi yang lain dan bukan Allah. Untuk itu, konsep klasik tentang Allah (omnipotence, omniscience, omnipresence) yang selama ini dipahami perlu didefinisikan ulang (Setiawidi, 2014). Sebuah ungkapan klasik seringkali kita dengar: "Tuhan tidak memberi apa yang kita inginkan tapi ia memberikan apa yang kita butuhkan." Sepintas hal tersebut mengandung kebenaran. Akan tetapi hal tersebut belumlah lengkap. Tuhan adalah pribadi yang tidak terbatas dan tidak dapat dibatasi. Ia memberikan apa yang manusia butuhkan, apa yang manusia minta atau inginkan, tetapi Tuhan juga memberikan apa yang tidak diminta oleh manusia. Setiawidi mengatakan, "Allah dalam Alkitab bukanlah Allah yang konstan. Ia bahkan adalah Allah yang tak terduga, Allah yang tak dapat dimengerti, dan tidak dapat dijinakkan oleh manusia karena Ia adalah Allah" (Setiawidi, 2014). Bagi keluarga pada masa kini yang belum mempunyai keturunan, hal ini berarti bahwa Allah di dalam misteri dan kebebasannya mungkin belum atau bahkan memang tidak akan memberikan anugerah berupa keturunan. Anugerah itu adalah hak Allah sendiri dan dengan demikian tidak dapat dipaksakan, hanya dapat diusahakan.

\section{Teologi Kontekstual yang Ditawarkan: Kesetaraan}

Menurut penulis, teologi kontekstual yang dapat dibangun atau ditawarkan adalah teologi kesetaraan. Hubungan antara laki-laki dan perempuan dalam masyarakat, seringkali bersifat dominasi-subordinasi atau superior-inferior. Hal inilah yang harus harus dikoreksi. Isu yang diangkat dalam tulisan ini yaitu persoalan keturunan dan kemandulan di dalam sebuah keluarga sebenarnya dipengaruhi kuat oleh pemahaman akan pengakuan terhadap peran dan kedudukan lakilaki dan perempuan yang sangat timpang. Jika masing-masing pihak dapat saling menghormati sebagai sesama ciptaan Tuhan yang setara, niscaya berbagai persoalan yang terkait dengan masalah keturunan dapat diselesaikan dengan lebih bijaksana.

Jika laki-laki menyadari bahwa perempuan adalah sesama ciptaan Allah yang segambar, sama seperti laki-laki, maka sudah sepatutnya seorang laki-laki menghormati perempuan dan tidak bersikap meremehkan, mempersalahkan, melecehkan, dan merendahkan. Demikian pula sebaliknya, perempuan atau istri tunduk kepada suaminya bukan karena takut atau semata-mata karena kewajiban tetapi karena ia sungguh-sungguh menaruh respek, hormat dan kasih kepadanya. Apabila terjadi masalah dalam hidup berumah tangga (termasuk dalam hal keturunan), masing-masing tidak 
mencari-cari atau saling melempar kesalahan. Jika masing-masing saling menghormati dan mengakui, maka masing-masing pihak dapat bekerjasama dalam menanggung berbagai persoalan, pergumulan, dan tekanan hidup. Ketika yang satu lemah, yang lain dapat menopang dan memberikan penghiburan serta kekuatan. Hal ini berarti pemahaman teologis yang menekankan dominasi-subordinasi perlu digantikan dengan pemahaman teologis yang mengakui dan menjunjung kesetaraan sebab baik laki-laki maupun perempuan sama-sama diciptakan oleh Allah untuk saling mengisi dan memperlengkapi satu sama lain.

Upaya mewujudkan kesetaraan bukanlah sesuatu yang baru karena hal tersebut juga turut diperjuangkan oleh teologi pembebasan dan teologi feminis. Akan tetapi kesadaran tersebut harus terus menerus ditumbuhkan dan dikembangkan untuk membebaskan baik perempuan maupun lakilaki. Semangat kesetaraan merupakan semangat yang diusung untuk membebaskan manusia dari setiap belenggu maupun tembok pemisah yang justru menghalangi manusia untuk hidup secara otentik dalam seluruh aspek hidupnya, dalam relasinya dengan sesama, dengan alam, dengan dunia ciptaan Allah.

\section{Kesimpulan}

Kehadiran seorang anak menjadi dambaan setiap keluarga. Ketidakhadirannya dianggap sebagai kekecewaan dan penderitaan bagi pasangan suami istri. Dalam konteks zaman itu, ketiadaan anak bukanlah pilihan bagi perempuan di zaman Perjanjian Lama. Status dan kedudukan mereka sedikit banyak dipengaruhi oleh kemampuannya dalam melahirkan anak-anak. Ketiadaan anak pertama-tama dipandang sebagai kekurangan sekaligus kesalahan seorang perempuan/ istri. Pada masa kini, kemandulan tersebut juga seringkali menjadi salah satu problematika dalam hidup berkeluarga. Dalam konteks masyarakat Indonesia kehadiran seorang anak seringkali masih menjadi sesuatu yang dianggap wajib dalam perkawinan. Bagi sebagian besar keluarga, kemandulan atau ketiadaan anak masih sukar untuk dianggap sebagai bagian dari berkat dan rencana Tuhan. Hal ini berarti diperlukan sebuah usaha yang tidak mudah dari gereja untuk memberikan pemahaman yang tepat sampai pada satu titik dalam perjalanan iman mereka masing-masing, pasangan suami istri dapat menerima kehendak Allah yang tidak dapat mereka mengerti itu dalam hidup mereka. Gereja perlu mengingatkan bahwa tujuan pernikahan bukan sekadar untuk memperoleh keturunan melainkan membangun kehidupan keluarga yang setara dan bahagia. Selain itu diperlukan usaha untuk mengingatkan dan menyadarkan setiap warga jemaat akan peran dan kedudukan perempuan sebab dalam masalah kemandulan, pihak perempuan seringkali menjadi pribadi yang dipersalahkan karena kedudukannya yang dipandang lemah. Gereja perlu mengingatkan bahwa tiada laki-laki tanpa perempuan. Laki-laki akan senantiasa membutuhkan perempuan sebagaimana dikatakan oleh Paulus dalam 1Korintus 11:11-12 "Namun demikian, dalam Tuhan tidak ada perempuan tanpa lakilaki dan tidak ada laki-laki tanpa perempuan. Sebab sama seperti perempuan berasal dari laki-laki, demikian pula laki-laki dilahirkan oleh perempuan; dan segala sesuatu berasal dari Allah." Kesadaran akan adanya kebutuhan tersebut seharusnya membuat laki-laki (suami) mengasihi dan menghormati perempuan (istri) sebagai pasangan hidupnya dan sebagai sesama ciptaan Allah yang setara. Reinterpretasi terhadap teks-teks Kitab Suci pada gilirannya memperlihatkan bahwa relasi dominasi-subordinasi yang selama ini terbentuk dapat dikikis, demi menghasilkan semangat yang membebaskan dalam relasi antara pasangan suami istri, sebuah teologi biblika kontekstual yang seharusnya menjunjung tinggi nilai-nilai kemanusiaan.

\section{Referensi}

Albertz, R., \& Schmitt, R. (2012). Family and Household Religion in Ancient Israel and the Levant. Winona Lake: Eisenbrauns.

Ashmon, S., \& Weise, R. W. (1988). Give Me Children, or I Will Die: Procreation Is God's Work. Concordia Journal, 337-345.

Bevans, S. B. (1992). Models of Contextual Theology. Maryknoll: Orbis Book.

Brueggemann, W. (1982). Genesis, Interpretation: A Bible Commentary for Teaching and Preaching. Atlanta: 
Westminster John Knox Press.

Byron, J. (2010). Childlessness and Ambiguity in the Ancient World. Conversations with the Biblical World: Proceedings of the Eastern Great Lakes Biblical Society \& Midwest Region Society of Biblical Literature, 17-46.

De Vaux, R. (1997). Ancient Israel: Its Life and Instructions. Grand Rapids: eerdmans Publishing.

Derck, S. (2002). Barrenness in the Old Testament: Recovering the Metaphor. Nazarene Theological Seminary.

Havrelock, R. (2008). The Myth of Birthing the Hero: Heroic Barrenness in the Hebrew Bible. Biblical Interpretation, 16, 154-178.

Hurley, J. B. (1981). Man and Woman in Biblical Perspective. Michigan: Zondervan.

Karman, Y. (2004). Bunga Rampai Teologi Perjanjian Lama. Jakarta: BPK Gunung Mulia.

Kvam, K. E., Schearing, L. S., \& Ziegler, V. (1999). Eve and Adam: Jewish, Christian, and Muslim Readings On Genesis and Gender. Indianapolis: Indiana University Press.

Marsman, H. J. (2003). Women in Ugarit and Israel: Their Social and religious Position in the Context of the Ancient Near East. Leiden: Brill.

Meyers, C. L. (1988). Discovering Eve: Ancient Israelite Women in Context. New York: Oxford University Press.

Meyers, C. L. (1997). The Family in Early Israel. In D. S. Browning \& I. S. Evison (Eds.), Families in Ancient Israel (pp. 1-47). Louisville.

Naimah. (2015). Perlindungan Hukum Terhadap Hak Kesehatan Reproduksi Perempuan Dari Kekerasan Berbasis Gender. Egalita, 10(1), 1-10.

Panigoro, M. R. (2020). Perempuan dan Kesialan “Kritik atas Pemahaman Khaled Abou el Fadl tentang Hadits Perempuan Pembawa Sial." Setara: Jurnal Studi Gender Dan Anak, 2(1), 48-65.

Perdue, L. G. (1997). The Israelite and Early Jewish Family: Summary and Conclusions. In D. S. Browning \& I. S. Evison (Eds.), Families in Ancient Israel. Louisville: Westminster John Knox Press.

Purnomo, A. (2013). Antara Kontrak dan Cinta: Perkawinan dalam Perjanjian Lama. Wacana Biblika, 13(1), 3-10.

Sanjaya, V. I. (2014). Nasib Perempuan-perempuan Mandul dalam Alkitab. Wacana Biblika, 14(1), $19-27$.

Setiawidi, A. (2014). Siapakah yang akan Menjembatani Jurang Itu? Orasi Dies natalis ke-80 STT Jakarta. Jakarta: UPI STT Jakarta.

Soskice, J. M. (1992). Can A Feminist Call God "Father"? In A. F. Kimel Jr. (Ed.), Speaking the Christian God: The Holy Trinity and Challenge of Feminism (pp. 78-91). Grand Rapids: Eerdmans publishing Company.

Susanta, Yohanes K. (2017). Makna Teologis Keturunan sebagai Pemberian Allah bagi Keluarga dalam Perjanjian Lama. Jurnal Teologi, 6(2), 143-154. https://doi.org/10.24071/jt.v6i2.998

Susanta, Yohanes Krismantyo. (2019). Sentana Rajeg Dan Nilai Anak Laki-Laki Bagi Komunitas Bali Diaspora Di Kabupaten Konawe. Harmoni, 18(1), 504-518. https://doi.org/10.32488/harmoni.v18i1.336

Susanti, S., \& Nurchayati. (2019). Menikah Tanpa Keturunan: Masalah Psikologis Yang Dialami Perempuan Menikah Tanpa Anak Dan Strategi Coping Dalam Mengatasinya. Character: Jurnal Penelitian Psikologi, 6(1), $1-13$.

Trible, P. (1983). God and the Rhetoric of Sexuality (W. Brueggemann \& J. R. Donahue, Eds.). Philadelphia: Fortress Press.

Van der Toorn, K. (1994). From Her Cradle to Her Grave: The Role of Religion in the Life of the Israelite and the Babylonian Woman. Sheffield: Sheffield Academic Press.

(C) 2020 by the authors. Submitted for possible open access publication under the terms and conditions of the Creative Commons Attribution (CC BY SA) license (https://creativecommons.org/licenses/by-sa/3.0/). 